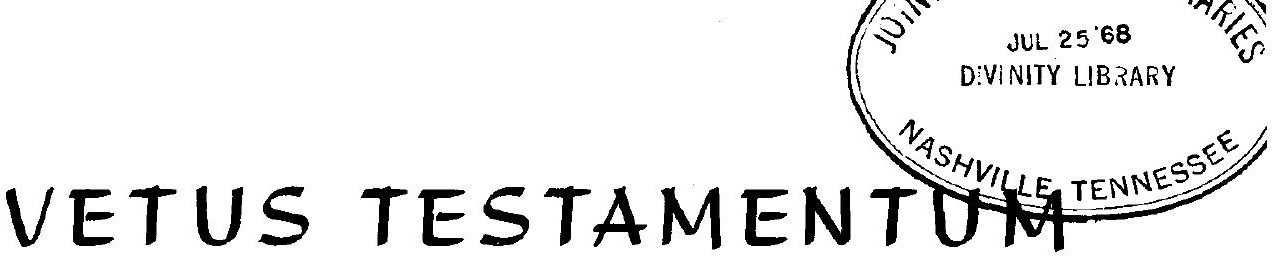

QUARTERLY PUBLISHED BY THE

INTERNATIONAL ORGANIZATION FOR THE STUDY OF THE OLD TESTAMENT

Vol. XVIII

$$
\text { JULY } 1968
$$

No. 3

\title{
CONTENTS
}

W. BAARS, The Peshitta Text of Song of Songs in Barhebraeus'

Aușar rāzēe . . . . . . . . . . . . . . . . . . . . . . . 281

M. Delcor, Les sources du chapitre VII de Daniel . . . . . . 290

T. E. FRetherm, The Priestly Ducument: anti-temple? . . . . . . 313

S. JAPHET, The supposed common authorship of Chron. and Ezra-

Neh. investigated anew ... . . . . . . . . 330

J. T. WILLIS, Some suggestions on the interpretation of Micah I 2 . 372

J. M. SAsson, Bovine symbolism in the Exodus narrative . . . . 380

SHORT Notes. . . . . . . . . . . . . . . . . . . . . . . 388

A. S. VAN DER Woude, Micha II 7a und der Bund Jahwes mit Israel. - J. Max Miluer, So Tibni died (1 Kings xvi 22). - S. P.

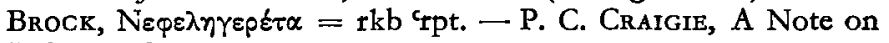
Judges $\mathrm{V} 2$.

REVIEWS . . . . . . . . . . . . . . . . . 400

C. RIETzSCHEL, Das Problem der Urrolle. Ein Beitrag zur Redaktionsgeschichte des Jeremiabuches (W. L. Holladay)

BookLIST ................... 406

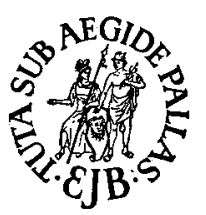

LEIDEN

E. J. BRILL 


\title{
MOTICE: This watortal May \\ pe Proteoted By Cowyight \\ Law (Tils 97 U.8. Code.)
}

\section{BOVINE SYMBOLISM IN THE EXODUS NARRATIVE *}

BY

\author{
JACK M. SASSON \\ Chapel Hill, North Carolina
}

Should one be in a position to accost a Hebrew of the early first millennium B.C. and question him regarding the meaning of the name Moses, he would no doubt be referred to Ex. ii 10. There it is said that when the child, who had been entrusted to his natural mother for feedings during the early months of his life, grew up, Jochebed brought him to the daughter of Pharaoh who adopted him and called him Mošeh, "kî̀ min-bammāyim mešit tîbu, for I have drawn him forth from the water."

Scholarship has, unfortunately, not been satisfied with such an explanation. The fact that the name $M$ oše $h$ is properly an active participle of the verb $m \bar{a} s a \bar{a} h$ (thus, one who draws out) when the biblical explanation requires it to be a passive, is one reason for this doubt. Beginning with Josephus and Philo, if not earlier, the suggestion has been presented that "Môseh" was derived from the Egyptian language ${ }^{2}$ ). Nowadays the greater number of scholars have opted for $m s$, 'child' or the related grammatical form found in names such as Ramoses, Thutmoses, Ahmoses, etc. One major difficulty, however, has yet to be solved; and that is the unlikelihood of Hebrew $\xi$ being equivalent to Egyptian $s^{2}$ ).

* I would like to express my gratitude to Professors Hildegard Lewy of Hebrew Union College and Nahum M. SARNA of Brandeis University for having read and commented on this paper. Although they are not responsible for the ideas present within, their criticism was most helpful and deeply appreciated. This paper was read at the 172nd Meeting of the Society for Biblical Literature, New York, December 28, 1966.

1) Various etymologies have been offered, most of which have found convenient documentation in J. Gwyn Griffiths, "The Egyptiañ Derivation of the Name Moses", JNES, 12 (1953), 225-26. O. SkrZYPCAK suggests an association with Ug. mšn, Enciclopedia de la Biblia, V, Barcelona, 1963, 244.

2) Cf. K. KItchen's comment in the New Bible Dictionary, London, 1962, p. 43. See, further, W. Helck, Die Beziehungen Ägyptens zu Virderasien ... (Ägypt. Abhand. $\mathrm{n}^{\circ}$ 5), Wiesbaden, 1962, p. 591, where he draws up a list of SemiticEgyptian consonantal correspondence. Note, further, his comments, p. 590, sub. $\forall ;$ p. 568, \198, 199, 194, 215. 
In 1965, Andrew F. Key published an interesting article based on notes and lectures of the late Julius LEWY. It was entitled "Traces of the Worship of the Moon God Sin among the Early Israelites." 1). The article argued that the ancestors of Israel, having been in Harran, were familiar with the cult of Sin and probably knew him in a bovine shape ${ }^{2}$ ). During the sojourn in Egypt, the cult was maintained. When they exited from Egypt, the Israelites were faced with continuing the worship of $\operatorname{Sin}$ in the form of a calf and inaugurating the worship of Yahweh ${ }^{3}$ ).

To be sure, such a hypothesis, and it is hardly more than that, generates many problems. For example, calf and bull worship were much too widespread throughout the Middle East - Apis in Egypt, $\mathrm{Ba} \mathrm{C}^{\mathrm{a}} \mathrm{l}$ in Ugarit, Tešub among the Hurrians - to permit an assured connection with Sin. Undoubtedly many biblical references to bovine figures can be clearly explained in reference to $\mathrm{Ba}$ 'alism, which on the whole was more immediate to the Israelites. But the discovery in Late Bronze Age Hazor of a moon-temple replete with symbolism of Sin and his consort Harranit permits one to speculate further into the problem ${ }^{4}$ ).

Among the many myths which the Akkadians told about their god Sin, one is preserved to us in the form of a spell to ease the pains of birthgiving. As it was told, there once was:

A cow (from the herd) of Sin, Amat-Sin was her name. She was bejeweled and voluptuous of figure. Sin saw her and fell in love with

1) $J B L, 84$ (1965), 20-26.

2) Note further that Sin was the personal god of Yarim-Lim of Yamhad, then, with its capital at Aleppo, the mightiest power in Western Asia (ca. 1800-1650), Dossin, "Une lettre de Iarîm-Lim, roi d'Alep, à Iašûb-Iaḩad, roi de Der", Syria, 33 (1956), 65:28. It is still a point of contention, however, whether Abraham's Ur was the famous Sumerian city or one further northwest, somewhere in the Harran area. See the important remarks of Siegfried Kirsr in "Sin, Yerah, und Jahwe: Eine Bemerkung zum vorderasiatischen Mondkult", Forscbungen und Fortscbritte, 32 (1958), 213-219.

3) JBL, 84 (1965), 26.

4) Hazor, a city whose fame as a trading center allowed it to play a role in the Mari era (cf. A. MaLAmat, "Hazor "The head of all those Kingdoms" ", JBL 79 (1960), 12-19), revealed late Bronze Age (from ca. 1300-1230) cult objects. Among the were a statue of a God on whose chest was incised a crescent, emblem of the Harranite Sin, and a stele depicting similar symbolism (Hazor $I$, Jerusalem, 1950, pp. 86-89; plates 29-31). A rectangular standard bearing the representation of a human face, flanked by two snakes, probably symbolizing Sin's spouse Harrânît (cf. H. LEwy, "Points of Comparison between Zoroastrianism and the Moon-cult of Harrân", in Studies in Honor of S. H. Taqizadeh, 1962, p. $141 \mathrm{ff}$.), and topped by the crescent of the moon-god (Hazor II, Jerusalem, 1960 , p. 117, plate 181 ). 
her. (But) the bewitchment of Sin drove her out of her senses. He placed her at the head of the herd, so that even the herdsmen had to follow her. They would take her to graze where the most succulent herbs were, and to drink at the best drinking places. Hidden from the shepherd-boys, where the herders could not see it, the fiery bull mounted the cow and violated her maidenhood. Then when her days ended and her months completed, the cow had terrible labor pains. Her herdsmen were melancholy, the shepherd-boys bewailed her, because of her moanings and groanings of labor pains which exhausted her.

Nannaru-Sin heard her groaning (while) in heaven. With his (strong) hand he lit up the heavens. Then two female guardian-demons came out of the heaven, one carrying an oil jar, while the other caused paineasing water to come out. They stroked her forehead with (the content) of the oil and poured the pain-easing water over her body. For the second time, she stroked her forehead with (the content) of the oil-jat and they poured the pain-easing water over the whole body. When they had stroked her forehead a third time, the calf fell to the ground as (easily) as the young of a gazelle. "Suckling-calf" [AMAR.GA, lit., 'a calf of milk'] he [Sin] named the calf ${ }^{1}$ ).

This motif was taken almost literally by the West-Semites, who wove it within epics concerned with $\mathrm{Ba}^{\mathrm{c} a l}$, the Storm-god, and 'Anat, his sister-wife, I AB(UT 67:V:17-23).

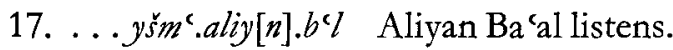
yubb.'glt.bdbr.prt He desires a heifer in the Pasture bśd.s.s lmmt.škb a cow in the field of ShImmt. He ${ }^{\prime} m n h . s b^{\prime} . l s^{\prime} b^{c} m \quad$ lies with her seventy seven times, [ ]ly.tmn.ltmnym [yea!] eighty eight times. $w[t b] r n . w t l d n m t \quad$ She conceives and bears $m t$ al [ ] slbšn She clothed him with a [?].

As we can see, except for the omission of the birth incident, which is quite understandable-given the nature of the Akkadian document - the two legends can be said to have had a common origin. In one of the Ugaritic variants of this incident (UT 75:1:15), Ba'al's mate is called Amt-Yrh, 'Handmaiden of the Moon-God,' an exact translation of Amat-Sin, thus confirming the dependence of the Ugaritic version on the Akkadian material 2). A Hurrian legend, preserved in Hittite Cuneiform and published by J. FrIEDRICH,

1) $\mathrm{KAI}, \mathrm{II} / 5$, u4., $\mathrm{n}^{\circ} 196$, rev. 10-32. The above is a free rendering of $\mathrm{F}$. M. Th. DE LIAGR E BöHL's Dutch translation published in his "Oud-Babylonische Mythen", $\$$ : De Maangod en de Koe, JEOL, 4 (1936), 203-204.

2) M. Astour, Hellenosemitica, Leiden, 1965, p. 86, n. 2. E. Lipiński, "Les conceptions et les couches merveilleuses de "Anath", Syria, 42 (1965), pp. $64 \mathrm{ff}$. 
permits one even to suppose these people to have been the transmitters ${ }^{1}$ ).

The birth of the calf $m t$ to $\mathrm{Ba}$ 'al and his heifer, can help us explain many striking elements which are associated with Moses. It can also help us bridge the gap between the Israelite calf and Yahweh worship.

It should be remembered, for the benefit of our discussion, that the Egyptian Delta where the Israelites sojourned during the second millennium B.C. was, and probably always had been, full of Asiatic enclaves. Semites began to filter into it as early as the VIIth dynasty (ca. 2200 B.C., M. Chron.) ${ }^{2}$ ). With the Hyksos they actually became quite dominant politically in that area ${ }^{3}$ ) and played a role in the foundation of Tanis/Avaris ${ }^{4}$ ). During the new kingdom, the Semites were quite successful in propagating their creeds among the Egyptians, an attempt which was no doubt aided by the Two-Lands Conquests in Asia ${ }^{5}$. Goshen, the region settled by the Hebrews, can most likely be located in the eastern Delta. Not far away were nomes in which bull and calf worship was practiced. ${ }^{6}$ ) As Symbols of fertility and strength, these animals embodied qualities which the Akkadians and Amorites associated with $\mathrm{Sin}$ and the Canaanites with Ba'al.

That Ugaritic $\mathrm{mt}$ was a possible cognate to Hebrew môseh ${ }^{7}$ ) has been suggested by Gordon and Astour. Gordon's derivation, however, came by way of Egyptian $m s^{8}$ ), which, as we have seen above, is rendered difficult because of the sibilants involved. Astour, on the other hand, etymologizes $m t$ from Akkadian $m u s$, 'serpent.' Although he offers many felicitous comparisons with ophic symbolism in the tribes of $\operatorname{Levi}^{9}$ ), it is difficult to accept his evidence which

1) "Churritische Märchen und Sagen in Hethitischen Sprache", $Z A, 15$ (1950), p. $224 \mathrm{ff}$. Note the close parallels between the late portion of this rendering with the Birth of Sargon legend and that of Moses.

2) Posener, "Les Asiatiques en Egypte sous les XIIe et XIIIe dynasties", Syria, 34 (1957), 145-63. Helck, Beziebungen, chap. 9, 10.

$\left.{ }^{3}\right)$ This despite Helck's arguments for Hurrian preponderance among the Hyksos, Beziehungen, chapter 13, an allegation that will not withstand close scrutiny.

4) Goedicke recently argued for a pre-Hyksos foundation of Tanis, possibly built to forestall their successes, "Some Remarks on the 400-Year-Stela", Chronique d'Egypte, 81 (1966), 23-39.

5) НЕLCK, Beziebungen, chapters 26, 32.

6) Е. Отто, Beiträge zur Geschichte der Stierkulte in Ägypten, Leipzig, 1938, pp. 6-8, 32, 33.

7) Note that Moses was a descendant of Le'ah, whose name meant "a cow." Cf. Akkadian litu, von Soden, Akk. HWb., 557.

8) UT 19:1579, p. 440.

9) Astour, Hellenosemitica, p. $229 \mathrm{ff}$. 
would permit bovines to parent a serpent ${ }^{1}$ ). In addition, the Akkadian parallel makes it quite plain that a calf was born out of the union.

In the following interpretation of Ex. xxxii 1-8 ${ }^{2}$ ), Moses' connection with the calf worshipped by the Hebrews is strongly intimated. The people of Israel had seen him who has led them out of Egypt disappear into the mountain. As they waited for his return, apprehension grew: Fearful that they had lost their leader, they demanded a symbol of his continued, reassuring presence be made. With this purpose in mind, they pleaded with Aaron: "Arise and make us gods who will go before us (i.e. lead us), for this Môšeh, the man who brought us out of Egypt, we do not know what has become of him." Aaron obliges and casts one statue of a calf. "They [Septuagint: he, i.e. Aaron] then shouted: These are your gods, Israel, who brought you out of Egypt."

The credit for the miracle of the Exodus having thus been given to Moses rather than to God, verses 7-8 can well be understood. "God spoke to Moses: Go down; for your people, which you bave brought out of Egypt have dealt corruptly. They have turned aside quickly out of the way which I have commanded them. They bave made for themselves a molten calf, and have worshipped it, and have sacrificed to it and said: these are your God, Israel, who bave brought you out of Egypt."

These repeated equations between Moses, the man who brought the Hebrews out of Egypt, and the calf, symbol of the deity that brought the people of Israel from bondage, render it plausible to assume that, to the newly-freed slaves, the molten calf was a substitute for Moses who had disappeared. In the ancient Near East it was not uncommon for certain animals, even inanimate objects, to represent deities and highly-esteemed personalities ${ }^{3}$ ).

1) Ibid., p. 89 ff. Note, for example, that in all the examples given in p. 90, fn. 1, there is not one case of cow-serpent/mother-child relationship. As to the quotation from Clement of Alexandria, it is quite nebulous in meaning.

2) Assigned to $E$ by Erssfeld T, The Old Testament, An Introduction, Oxford, 1965, p. 201. Many authors (e.g. I. Lewy, "The Story of the Golden Calf Reanalysed", ITT9 (1959), 319-21; M. Noтн, Exodus, Philadelphia, 1962, p. 246) regard certain verses in this passage as later interpolation of an Elohist, intent on condemning a cult which, in his own time, had become quite prevalent. But NotH adds (ibid.), "We can ask whether perhaps Ex. xxxii contains an older tradition of a cultic apostasy of Israel even on Sinai which was only later transformed into a polemic against the 'golden calves' of Jeroboam." See now the interesting article of M. Aberbach and L. Smoler, "Aaron, Jeroboam, and the Golden Calves", in $J B L, 86$ (1967), 129-140.

3) When, later in Hebrew history, the incident was retold, (as in Ps. cvi $19 \mathrm{ff}$., and Neh. ix 18), the equation was no longer remembered. 
Striking support of this interpretation can be gleaned from Ex. xxxiv 29-35 ${ }^{1}$, a passage which, as it has been suggested, may have followed Ex. xxxi 18a, and thus would have preceded the "golden calf" incident ${ }^{2}$ ).

And it was, as Moses came down from Mount Sinai with the two tablets of testimony in Moses' hand, when he came down from the mountain, Moses did not know that the skin of his face had become borned (i.e. developed horns) while he spoke to $\mathrm{Him}^{3}$ ). When Aaron and all the Israelites saw Moses, the skin of his face had become horned; so they feared approaching him. Moses, however, called to them; Aaron and all heads of the community returned to him. Moses, then, spoke to them. Afterwards all the Israelites approached and he communicated to them all that God commanded him on Mount Sinai. When Moses ended speaking with them he placed a veil upon his face. But when Moses would come before God in order to speak to Him, he would remove the veil until his exit. He would then depart and he would communicate what he was ordered to the Israelites. And the

1) Eissfeldt, op. cit., regards Ex. xxxiv 29-35 as penned by $P$. Noth, op. cit., p. 267, is not as sure: "Despite some elements of $P$ language which can, however, easily be cut out as additions ... the passage as a whole does not give the impression as coming from $P$. But a place cannot be found for it in $j$ either ... It is therefore probable that we have a special tradition [italics mine] ... which was perhaps associated with a few observations by $J$ about the descent of Moses and his report to the people...."

2) Bible de Jerusalem, Paris, 1961, p. 98, n. $f$.

3) It has been argued that horns do not usually protrude from facial areas. Indeed, the common depiction in Mesopotamian art shows deities bearing headgears with lateral protuberances. But, as is the case on some Ugaritic stelae, horns seem to rise from the forchead, or the frontal region (cf. Syria, 14 (1933), p. XVI; 31 (1954), pl. VIII).

Indeed, some passages in the Bible can best be understood where one substitutes 'forehead,' 'face' for the occurrence of 'horn,' thus demonstrating the close relationship between the two. For example, Job xvi 15: "I have sewn sack on my hide, and rolled my forehead in the dust" we ōlaltî be cäpär qarnit; cf. the Bible de Jerusalem, p. 617. Less clear is $1 \mathrm{Sa}$. ii 1: "Then Hannah prayed and said: My heart exults in YHWH, my face turns upward toward YHWH räma $\bar{a}^{h}$ qarnî ba- $Y H W H$, my mouth widens upon my enemies, for I rejoice in your aid."

. In "The Babylonian Background of the Kay Kâûs Legend", Arcbiv Orientálni, 17 (1949), p. $83 \mathrm{ff}$., H. LEwY suggests that horns project from the forehead of some Mesopotamian rulers, notably Naram-Sin of Agade, after an interview with a deity. While her examples of Su-Sin and Ibbi-Sin do not constitute good evidence, as they are not shown to be horned, those of Naram-Sin and Puzur-Ištar are clear. In the case of Naram-Sin, however, it is to be noted that the accompanying inscription reveals him to have been divinized before his victory over Satuni, king of Lullubi. See further Meissner, Babylonien und Assyrer, II, Heidelberg, 1925, p. 42 ff., and fig. 12, 13, 14, 18; and J. DE FRAINE, "Moses' "cornuta facies" ", B̈̈jdragen, 20 (1959), 28-37, who compares qeren with Sum. NÍ and Akk. melammu, which he considers to be a halo-like radiance. 
Israelites saw Moses' face-for the skin of his face had become horned - (but) Moses placed back his veil upon his face until he went in to speak with him.

The crux interpretum of this segment is, of course, the statement, qäran 'ôr pänäw, repeated in verses $29,30,35$. The usual translation "became shiny" is clearly deduced from context. Undoubtedly the Septuagint which translated this formula into $\delta \varepsilon \delta \delta \xi \alpha \sigma \tau \alpha$, "shone," did so also. Interestingly enough, the vulgate rendered cornuta erat facies sua, which no doubt inspired Michelangelo's famous Moses. In its Qal form, the verb qäran unfortunately appears only in the above example. As a verbal formation (Hiph il, part.), however, it occurs further in Ps. Ixix 32, pār maqrîn maprîs, "a bull who develops horns and parts the hoofs."

As a substantive, qeren, "horn" occurs approximately a hundred times, if one includes the Aramaic segments, in the O.T. Generally, the term denotes: (a) the "horn of a beast," the primary meaning; (b) a projection designed on the mizbe $a_{b}$; (3) a metaphor suggesting vanity, pride, force, dignity, and power.

When translating Ex. xxxiv 29-36, Hab. iii 4 is usually alluded to as a passage where qeren clearly means 'light.' If this be so, then Hab iii 4 offers, to my knowledge, the only example, out of almost a hundred instances in the O.T., where such a rendering can be exegeted. It should be remembered, however, that this passage has been recognized as full of difficulties, in some measures, even corrupt. Some scholars consider an entire stichos to have been lost. Others emend the text radically enough to change every word in the verse. For this reason, it seems imprudent to insist on employing it to clarify Ex. $x_{x x i v}{ }^{1}$ ).

What, in reality, is the purpose of this obscure incident? To be sure, the passage is full of other difficulties, among which are the nature symbolism and function of the masweh, usually translated "veil" 2); the interjection of Aaron and the people of Israel within

1) For some other relevant comments on Hab. iii 4, see Lewr, JBL 84 (1965), 24. M. DAнOOD translates qarnayim miyyādô lô, "two wings were at his side" basing himself on UT 76:II:21-23 where the qrn dbat of "Anat is understood as "wings of strength", "Ugaritic Lexicography", Mélanges Eugène Tisserant, I (Studi e Testi, 231) 1964, p. 95. This last rendition is disputed by E. Liprśski, Syria, 42 (1965), p. 69 and p. 69 n. 2, who insists on giving the meaning "horn" to qrn even in the Ugaritic material. See now also the comments of B. COUROYER, "Corne et arc", Revue Biblique, 73 (1966), p. 517. n. 32.

2) One expects the 'veil' to be placed on Moses' face when he spoke to the Hebrews, and removed when he stood before God. But in both the instances in 
the scene; the possibility, mentioned above, of its being displaced from its original position. It might be plausible, however, that Ex. xxxiv 29-35 serves to answer one of LEwy's questions: "How are the two traditions [one of worshiping Sin, the other of Yahweh] combined into the present narrative?" In this one vestige of a suppressed cult, this one single depiction of a horned Moses, symbolizing the old pagan faith, being brought face to face with the God of the new creed, YHWH asserts his dominance. It is He who gives the orders. Moses does no more than present them to the people. From then on, there is no more mention of horns, no more mention of veils. Monotheism triumphs, at least for the time being.

A bit more confirmation to our image of Moses as symbolized by a calf comes from the subsequent history of his descendent. To his son Gershom was born Jehonathan ${ }^{1}$ ). The last and his sons became priests to Dan, a tribe which was responsible for establishing an idolatrous worship some 30 kilometers northeast from moonworshiping Hazor. It is not surprising to learn that their objects of adoration were golden calves $(2 \mathrm{~K} \times 29)$, strongly hinting that some sort of an ancestor cult was being perpetuated ${ }^{2}$ ). In this manner, through Moses, a direct link to Sin, God of the Harranite Terah, seems to have been maintained.

which such scenes are described (verses 33, 35), Moses wore the 'veil' after he had met the Israelites and removed it before he approached God. He thus used it only in between times, if at all. The indications are very difficult to assess.

1) Accepting the widely acknowledged reading מֶֶֶ for in Jgs xviii 30, the last being a Massoretic emendation to save the honor of the house of Moses.

2) For Jeroboam's schism and its implication, see LEwY, JBL 84 (1965), 23-24. 